\section{Antithymocyte Globulin May Reduce Chronic Graft versus Host Disease in Patients Undergoing Unrelated Peripheral Stem Cell Transplantation}

Over the past few years peripheral blood stem cells have been increasingly used instead of bone marrow for allografting patients with hematologic malignancies. Peripheral blood stem cell transplantation is associated with major advantages like a more rapid neutrophil and platelet recovery as well as a faster immune reconstitution. However, several reports have also shown a significant higher incidence of chronic graft versus host disease (GVHD), particulary of extensive type, which is attributed to a 10- to 20fold increase in the number of $\mathrm{T}$ cells in the apheresis product. Recent articles confirmed this observation [1-3].

Preliminary results indicate that antithymocyte globulin (ATG) as part of the pretransplant conditioning regimen is able to reduce the incidence of acute and chronic GVHD in patients undergoing related or unrelated allogeneic bone marrow transplantation for various hematologic malignancies [4-7]. Since unrelated peripheral blood stem cell grafts might bear an even higher risk of chronic GVHD, we incorporated rabbit anti-human T-lymphocyte globulin (ATG Fresenius, Munich, Germany) into our conditioning regimen. ATG was given at a daily dose of $20 \mathrm{mg} / \mathrm{kg}$ administered as a 4-hourinfusion on 4 consecutive days (days -4 through -1 ). Three patients transplanted with this regimen are evaluable for the assessment of chronic GVHD. Conditioning in these cases consisted of fractionated TBI $(3 \times 4 \mathrm{~Gy})$ and cyclophosphamide $(120 \mathrm{mg} / \mathrm{kg})$, GVHD prophylaxis of cyclosporine A, and a short course of methotrexate in addition to ATG. In all patients the grafts were derived from HLA A-, B- and DRidentical unrelated healthy donors, the number of CD34+ peripheral blood stem cells was $6,3 / \mathrm{kg}$ b.w. in patient No. 1 and 4.4 and $19.3 / \mathrm{kg}$ b.w. in patients No. 2 and 3, respectively.

Patient No. 1 was a 23-year-old male Caucasian who was transplanted for refractory acute lymphoblastic leukemia (ALL). He never experienced acute or chronic GVHD, but relapsed 6 months after successful engraftment and expired despite donor lymphocyte infusion therapy. The second patient was a 42-year-old male Caucasian who was allografted with a onelocus $\mathrm{C}$ mismatch donor for Philadelphia-positive chronic myeloid leukemia in first chronic phase after a 1-year course of interferon-alpha therapy. After an observation period of 395 days he is in molecular remission and showed only transient limited chronic GVHD of the skin related to discontinuation of cyclosporine A. Reinstitution of the drug was rapidly followed by complete resolution of the skin rash.

The third patient, a 48-year-old female Caucasian, has been allografted for acute myeloid leukemia in second complete remission. Chimerism studies by analysis of variable numbers of tandem repeats (=VNTR) show full donor hematopoiesis and after an observation period of 270 days she is in continued complete molecular remission and does not show any signs of either acute or chronic GVHD.

These 3 cases suggest that the addition of ATG to the conditioning regimen can modify GVHD in patients undergoing unrelated peripheral blood stem cell transplantation. However, it may be counterbalanced by a higher rate of relapses and infectious complications. Therefore, prospective randomized trials are warranted in order to determine the value of this novel approach.

P. Neumeister, W. Zinke, H. Sill, W. Linkesch, Graz

\section{References}

1 Storek J, Gooley T, Siadak M, Bensinger WI, Maloney DG, Chauncey TR, Flowers M, Sullivan KM, Witherspoon RP, Rowley SD, Hansen JA, Storb R, Appelbaum FR: Allogeneic peripheral blood stem cell transplantation may be associated with a high risk of chronic graft-versus-host disease. Blood 1997;90:4705.

2 Kalayoglu-Besisik S, Budak-Alpdogan T, Nuri Yenerel M, Sargin D, Tangün Y: High risk of chronic graft-versus-host disease in unmanipulated allogeneic peripheral blood stem cell transplantation. Blood 1998;92:2973.

3 Majolino I, Saglio G, Scime R, Serra A, Cavallaro AM, Fiandaca T, Vasta S, Pampinella M, Catania P, Indovina A, Marceno R, Santoro A: High incidence of chronic GVHD after primary allogeneic peripheral blood stem cell transplantation in patients with hematologic malignancies. Bone Marrow Transplant 1996;17: $555-560$.

4 Holler E, Ledderose G, Knabe H, Muth A, Günther C, Wilmanns W, Kolb HJ: ATG serotherapy during pretransplant conditioning in unrelated donor BMT: Dose depending modulation of GVHD. Bone Marrow Transplant 1998;21:30.

5 Stockschläder MAR, Grimm J, Hassan HT, Arland M, Löliger C, Clausen J, Horstmann M, Kabisch H, Zander AR: Antithymocyte globulin as part of the pretransplant regimen may reduce transplant related morbidity and mortality in chronic myelogenous leukemia patients undergoing allogeneic bone marrow transplantation. Haematol Blood Transfus 1998;39:1103.

6 Kolb HJ, Holler E, Knabe H, Ledderose G, Mittermueller J, Schleuning M, Mayer F, Goldmann SF, Fischer M, Lorenz T, Hill W, Schuh R: Conditioning treatment with antithymocyte globulin (ATG) modifies graft-versus-host disease in recipients of marrow from unrelated donors. Blood 1995;86:952a.

7 Kröger N, Zabelina T, Krüger W, Renges H, Rüssmann B, Dürken M, Stockschläder M, Ertmann R, Kabisch H, Zander AR: Anti-human T-lymphocyte globulin (ATG) as part of conditioning regimen in unrelated bone marrow transplantation of patients with CML in chronic or accelerated phase. Blood 1998;92:144a.

\begin{tabular}{ll}
\hline KARGER & @ 1999 S. Karger GmbH, Freiburg \\
Fax +49 7614520714 & Accessible online at: \\
$\begin{array}{l}\text { E-mail kargergmbh@aol.com } \\
\text { www.karger.com }\end{array}$ & http://BioMedNet.com/karger
\end{tabular}

